\title{
Biotechnological methods of managing the production processes of grape plants
}

\author{
Dmitriy Russo, Galina Aleynikova, and Elena Ilnitskaya \\ Federal State Budget Scientific Institution «North Caucasian Federal Scientific Center of \\ Horticulture, Viticulture, Wine-making», str. 40 Let Pobedy, 39, Krasnodar, 350901, Russia
}

\begin{abstract}
In viticulture, despite the fact that the main commodity producers have fairly modern technologies for the production of grapes, there are trends in the need to modify raw materials production technologies that meet the requirements for the production of high-quality products, reduce production costs, its biologization. Also, the problem of selecting varieties for a specific agro-ecological zone and increasing the production of table grapes, which requires certain research in the justification of design decisions, became actual.
\end{abstract}

At this time, the development of the wine industry of the agro-industrial complex is one of the priorities of the agrarian policy of Russia and is aimed not only at increasing the volume of its own production, but also at developing the economy of the grape-producing subjects of the Russian Federation

Relevant in the near future will be such technologies that will be able to ensure the competitiveness of the production of grapes and its processed products, ecologization, biologization and resource conservation of all technological processes by new methods and ways.

Among the distinctive features of the competitiveness of the technology, its prospects should include:

- high productivity of plantings for the entire period of operation, which will provide the required level of production profitability;

- consistently high yields, which characterize the resistance of the vineyard to stress factors of various nature, and also allow to achieve a reduction in cost;

- a long productive period of ampelocenosis, which characterizes all design solutions that contribute to the realization of the biological potential of varieties, variety-rootstock combinations; high quality of the obtained products.

In connection with the above, it should be that the following scientific and practical tasks will have a priority focus in the foreseeable period:

accelerated breeding of varieties with a complex of economically valuable traits that are resistant to the most harmful diseases and pests;

expanding the boundaries of plant resistance to adverse environmental stress factors.

Biologization plays a priority role in reducing the level of anthropogenic impacts on ampelocenosis, leveling negative manifestations.

Biolgization is understood as a system of organizational and technical measures aimed at using the laws of nature, improving the soil, reducing the energy intensity of processes and 
the cost of production, as well as increasing profitability, product quality through the scientifically based application of techniques for activating vital processes in plants, reducing energy consumption and using biological ways and methods for this purpose.

For modern viticulture, the most relevant areas are organic and biodynamic production, which imposes increased requirements for the breeding of new grape varieties. The ideal grape variety in the modern understanding should have stable productivity, complex stability and give a high-quality yield $[1,2]$.

Such an example is the Vladimir variety, which is characterized by a weak infectability of fungal diseases and high resistance to frost $\left(-27^{\circ} \mathrm{C}\right)$. At the same time, the tasting assessment of table wines is 7.8-8.0 points.

The Dmitriy variety shows high resistance to fungal diseases and tolerance to the root form of phylloxera, which allows it to be grown in an own-rooted culture. It is characterized by increased resistance to frost $\left(-25^{\circ} \mathrm{C}\right)$. The tasting assessment of table wines is 7.7-7.9 points.

The process of creating new plant forms is based on the use of their genetic diversity, and the success of breeding works is largely determined by the creation of genotypes with a complex of genes of resistance to major pathogens, replenishment and study of the gene pool of grapes in ampelographic collections [3-8].

The strategy of creating new competitive varieties is based on the search for donors of valuable traits, clarifying the mechanisms of inheritance of traits and optimizing the breeding process [9-10].

Thus, our scientific center is working on the search for donors of mildew resistance genes $R p v 3, R p v 10$ and $R p v 12$ in the genotypes of grape varieties and forms using DNA markers.

Modern methods of genetics and molecular biology, such as DNA-marker breeding, significantly expand the possibilities of research in this direction, creating a fundamental basis for breeding and offering tools for improving the selection process [11-13].

The competitiveness and efficiency of production are largely related to the natural and climatic conditions and the peculiarities of grape cultivation, which is reflected in the placement of the varietal composition, the zonal specifics of the applicated agricultural technologies.

According to the analysis of the database, which included the study of agro-climatic indicators at 28 weather stations for 15 years, the predominance of the use of varieties and clones of domestic breeding ensures high plant adaptability, productivity and quality. These signs are most valuable, manifest themselves in the places of origin of plants, and are not characteristic of introducers. The isothermal maps and isohyet maps compiled by us, which were superimposed on the soil map, confirm these conclusions. 5 agroecological zones and 47 subzones of homogeneous territories were also identified during layering, with the selection of criteria that take into account the greatest influence of factors on plant ontogenesis.

In-depth zoning of the territory helped to identify and ensure the conditions for growing grapes that contribute to an increase in the productivity of plantings by $30-40 \%$; improving the quality of products by such indicators as an increase in sugar in grapes (by $1-2 \mathrm{~g} / 100$ $\mathrm{cm}^{3}$ ); extending the productive life of plantings (by 1.5-2 times); reducing the cost of viticulture products without additional capital investments.

Zonally oriented grape varieties help to reduce costs in the technological process, increase the competitiveness of domestic viticulture, fully participate in import substitution, and renewable natural energy sources are used more efficiently. Zonally oriented varieties are able to effectively realize their productive potential, while growth processes are provided with natural resources in the most favorable ratio [14-15]. 
The main task of our research is to assess the level of use of grape varieties with production potential to study the conditions for their introduction in the moderate continental climate of the south of Russia. This work is also of interest for the selection of adaptive grape varieties that allow to get high yields and high-quality wines.

The average yield of the studied varieties is in a very wide range from 3.15 to $13.0 \mathrm{t} / \mathrm{ha}$ when grown in typical weather and climatic conditions. In more than half of the studied varieties (54\%), the yield varied from 5.0 to $10.0 \mathrm{t} / \mathrm{ha}$. In $23 \%$ of the varieties, the yield was low and did not exceed $5.0 \mathrm{t} / \mathrm{ha}$, while in $23 \%$ of the varieties, the yield was high from 10.0 t/ha or more. Under the same conditions of growing grapes, there are large differences in yield between the studied varieties, which is due, firstly, to their biological characteristics, and secondly, to their origin and adaptive potential.

Thus, more than a third of the studied varieties (37\%) have a very low production potential in specific climatic conditions, barely reaching $50 \%$. Another $60 \%$ of varieties realize their potential unsatisfactorily. Only $23 \%$ of varieties realize their potential by $70 \%$, which is a satisfactory indicator of the realization of the potential of economic productivity. Of the 35 varieties analyzed, only one has a high level of productivity realization, exceeding $80 \%$.

A high dependence is noted between the origin of varieties and its realization of economic productivity.

The task of breeding is to choose a variety whose biological characteristics correspond to the agroecological conditions of the growing environment as much as possible. This contributes to the implementation of adaptive indicators, obtaining maximum yields at the specified quality indicators.

Autochthonous varieties, varieties of breeding of the Anapa Zonal Experimental Station of Viticulture and Winemaking (Anapa) and the North Caucasian Federal Scientific Center of Horticulture, Viticulture, Wine-making (Krasnodar), the All-Russian Research Institute of Viticulture and Winemaking named after Ya. I. Potapenko (Novocherkassk) show the best level of realization of the potential of economic productivity of grapes in the Black Sea agroecological zone of viticulture.

However, for the development of nurseries that ensure the production of planting material in sufficient quantities and assortment, it is important to systematically pursue a varietal and technological policy.

It is safe to say that the recommended varieties of different maturation periods, colored and unpainted, for grafted and own-rooted culture are superior to similar Western European varieties. Consumer properties meet the requirements of both winemaking and the production of grapes for fresh consumption. Thus, table grape varieties are characterized by an attractive appearance - color, shape, size of the cluster and berries, good taste qualities. In addition, it is planned to create a conveyor for the consumption of fresh grapes for a long period from the third decade of July to the second decade of October.

The restoration of the system of domestic production of planting material and seedlings of the highest quality categories becomes especially relevant in the conditions of restrictions on the import of seedlings infected with quarantine objects into the territory of the Russian Federation.

An indispensable condition for the production of healthy planting material at the present stage of viticulture development is the application of biotechnological techniques. One of them is microclonal reproduction. No less important are such techniques as phytosanitary selection, testing of plants using modern diagnostic methods, testing for viruses, phytoplasmas, viroids and bacteria. it is necessary to carry out procedures for improving the planting material of grapes when detecting infections, as well as laying, maintaining and forming mother plants of the original category. 
Thus, in order to create long-lasting and highly productive plantings from promising varieties and clones in Russia, it is necessary to create on the basis of the formed bank of genetic resources and genetic collections of a fundamentally new generation of grape varieties and clones, introduced varieties, adapted to local agroecological conditions and transition to laying industrial plantings with certified planting material.

\section{References}

1. E. A. Egorov, V. S. Petrov, Bulletin of the Russian Agricultural Science, 5, 51-54 (2017) https://www.vestnik-rsn.ru/vrsn/article/view/55

2. M. C. Ramos, F.M. de Toda, Eur. J. Agron., 115, 126014 (2020) https://doi.org/10.1016/j.eja.2020.126014

3. A. Martínez-Moreno, F. Sanz, A.Yeves, R. Gil-Muñoz, V. Martínez, D.S. Intrigliolo, I. Buesa, Sci. Hortic., 256, 108614 (2019) https://doi.org/10.1016/j.scienta.2019.108614

4. Yu. Hou, F. Wu, Ya. Zhao, L. Shi, X. Zhu, Sci. Hortic., 256, 108607, (2019) https://doi.org/10.1016/j.scienta.2019.108607

5. L. Bascuñán-Godoy, N. Franck, D. Zamorano, C. Sanhueza, D.E. Carvajal, A. Ibacache, Sci. Hortic., 218, 284-292 (2017) https://doi.org/10.1016/j.scienta.2017.02.034

6. S.Ortega-Farias C.Riveros-Burgos, Sci. Hortic., 250, 38-44 (2019) https://doi.org/10.1016/j.scienta.2019.02.025

7. G. Gutiérrez-Gamboa, N. Alañón-Sánchez, R. Mateluna-Cuadra, N.Verdugo-Vásquez, Food Res. Int., 136, 109477 (2020) https://doi.org/10.1016/j.foodres.2020.109477

8. Zs. Zsófi E. Tóth, D. Rusjan, B. Bálo, Sci. Hortic., 127, 494-499 (2011) https://doi.org/10.1016/j.scienta.2010.11.014

9. S. Masia, A. Trabucco, D. Spano, R.L. Snyder, J. Sušnik, S. Marras, Agric. Water Manag., 255, 107005 (2021) https://doi.org/10.1016/j.agwat.2021.107005

10. A. Sabir, H. Kucukbasmaci, Sci. Hortic., 272, 109589 https://doi.org/10.1016/j.scienta.2020.109589

11. E. Ilnitskaya, M. Makarkina, S. Tokmakov, V. Kotlyar, BIO Web Conf., 25. P. 03004 (2020) https://doi.org/10.1051/bioconf/20202503004

12. E. T. Ilnitskaya, S.V. Tokmakov, M.V. Makarkina, I. Suprun, Acta Hortic., 1248, 129134 (2019) $10.17660 /$ ActaHortic.2019.1248.19

13. E.T. Ilnitskaya, M.V. Makarkina, S.V. Tokmakov, L.G Naumova, Vavilov J. Gen. Breed., 22(6), 703-707 (2018) https://doi.org/10.18699/VJ18.413

14. V.S. Petrov, G.Yu. Aleynikova, A.A. Marmorstein, Agroecological zoning of the territory for optimizing the placement of varieties, sustainable viticulture and high-quality winemaking, 138 (NCFSCHVW, Krasnodar, 2020)

15. R.M. de Orduña, Food Res. Int., 43(7), 1844-1855 (2010) https://doi.org/10.1016/j.foodres.2010.05.001 